\title{
Murine roseolovirus does not accelerate amyloid- $\beta$ pathology and human roseoloviruses are not over-represented in Alzheimer disease brains
}

Tarin M. Bigley ${ }^{1 \dagger}$, Monica Xiong ${ }^{2,3,4 \dagger}$, Muhammad Ali ${ }^{6}$, Yun Chen ${ }^{2,3,5}$, Chao Wang ${ }^{2}$, Javier Remolina Serrano ${ }^{2}$, Abdallah Eteleeb ${ }^{6,7}$, Oscar Harari ${ }^{2,6,7}$, Liping Yang ${ }^{8}$, Swapneel J. Patel ${ }^{8}$, Carlos Cruchaga ${ }^{2,6,7}$,

Wayne M. Yokoyama ${ }^{8^{*}}$ and David M. Holtzman ${ }^{2^{*}}$ (D)

\begin{abstract}
Background: The role of viral infection in Alzheimer Disease (AD) pathogenesis is an area of great interest in recent years. Several studies have suggested an association between the human roseoloviruses, HHV-6 and HHV-7, and AD. Amyloid- $\beta$ (AB) plaques are a hallmark neuropathological finding of $A D$ and were recently proposed to have an antimicrobial function in response to infection. Identifying a causative and mechanistic role of human roseoloviruses in $\mathrm{AD}$ has been confounded by limitations in performing in vivo studies. Recent -omics based approaches have demonstrated conflicting associations between human roseoloviruses and AD. Murine roseolovirus (MRV) is a natural murine pathogen that is highly-related to the human roseoloviruses, providing an opportunity to perform well-controlled studies of the impact of roseolovirus on $A \beta$ deposition.

Methods: We utilized the 5XFAD mouse model to test whether MRV induces A $\beta$ deposition in vivo. We also evaluated viral load and neuropathogenesis of MRV infection. To evaluate A 3 interaction with MRV, we performed electron microscopy. RNA-sequencing of a cohort of AD brains compared to control was used to investigate the association between human roseolovirus and AD.

Results: We found that 5XFAD mice were susceptible to MRV infection and developed neuroinflammation. Moreover, we demonstrated that $A \beta$ interacts with viral particles in vitro and, subsequent to this interaction, can disrupt infection. Despite this, neither peripheral nor brain infection with MRV increased or accelerated A $\beta$ plaque formation. Moreover, -omics based approaches have demonstrated conflicting associations between human roseoloviruses and AD. Our RNA-sequencing analysis of a cohort of AD brains compared to controls did not show an association between roseolovirus infection and AD.
\end{abstract}

\footnotetext{
*Correspondence: yokoyama@wustl.edu; holtzman@wustl.edu

†Tarin M. Bigley and Monica Xiong contributed equally to this work.

${ }^{8}$ Division of Rheumatology, Department of Medicine, Washington University

School of Medicine, St. Louis, MO 63110, USA

${ }^{2}$ Department of Neurology, Hope Center for Neurological Disorders, Knight

Alzheimer's Disease Research Center, Washington University School of

Medicine, St. Louis, MO 63110, USA

Full list of author information is available at the end of the article
}

\section{$\triangle B M C$}

(c) The Author(s). 2022 Open Access This article is licensed under a Creative Commons Attribution 4.0 International License, which permits use, sharing, adaptation, distribution and reproduction in any medium or format, as long as you give appropriate credit to the original author(s) and the source, provide a link to the Creative Commons licence, and indicate if changes were made. The images or other third party material in this article are included in the article's Creative Commons licence, unless indicated otherwise in a credit line to the material. If material is not included in the article's Creative Commons licence and your intended use is not permitted by statutory regulation or exceeds the permitted use, you will need to obtain permission directly from the copyright holder. To view a copy of this licence, visit http://creativecommons.org/licenses/by/4.0/ The Creative Commons Public Domain Dedication waiver (http://creativecommons.org/publicdomain/zero/1.0/) applies to the data made available in this article, unless otherwise stated in a credit line to the data. 
Conclusion: Although MRV does infect the brain and cause transient neuroinflammation, our data do not support a role for murine or human roseoloviruses in the development of $A \beta$ plaque formation and $A D$.

Keywords: Alzheimer's disease, Human roseolovirus, Murine roseolovirus, Amyloid-beta, Neuroinflammation

\section{Background}

In the past decades, major strides have been made to uncover the heterogeneous factors that contribute to the etiology of Alzheimer Disease (AD). Recent advancements in biomarker studies predict that amyloid- $\beta(A \beta)$ plaques begin to aggregate in the brains of $A D$ patients 15-20 years before the onset of cognitive symptoms. $A \beta$ accumulation triggers a local inflammatory response in the central nervous system (CNS) and promotes subsequent intracellular tau accumulation in the neocortex [1]. However, the initial events that drive $A \beta$ seeding remain under debate and recently, pathogens have been raised as contributing factors. Although the mechanistic contributions of pathogens are unclear, multiple pathogens have been associated with AD. Recent studies have suggested that $A \beta$ may act as an antimicrobial peptide that binds to pathogens and limits their entry [2-6]. In these studies, $A \beta$ seeding was proposed to accelerate as part of an immune response to infection, and repeated or chronic infection results in persistent inflammation and $A \beta$ accumulation.

Herpesviruses have been considered in the pathogenesis of AD because they are ubiquitous in the population, cause chronic infections that periodically reactivate, and several herpesviruses, including herpes simplex viruses (HSV-1 and HSV-2), cytomegalovirus, EpsteinBarr virus, and the human roseoloviruses infect the CNS and cause neuroinflammation $[7,8]$. Indeed, the herpesviruses have been associated with $\mathrm{AD}$ [9-14]. The human roseoloviruses, HHV-6A, HHV-6B and HHV-7, have received particular attention given their link with CNS diseases, such as multiple sclerosis and encephalitis $[15,16]$. Moreover, there are reports of increased HHV6 DNA in AD brains compared to non-AD controls [17], decreased HHV-6 IgG titers in the blood of AD patients compared to controls [6], and a human leukocyte antigen subtype associated with increased susceptibility to HHV-6A infection that was suggested to be an AD genetic risk factor [18]. A recent publication by Readhead, et al. utilizing transcriptomic, genomic and proteomic analysis of several brain banks suggested a link between human roseoloviruses, specifically HHV-6A and HHV-7, and AD [19]. Furthermore, another study observed $A \beta$ aggregating around HHV-6 in vitro [5]. However, a reanalysis of the study published by Readhead, et al. using a different statistical methodology [20], as well as an additional cohort study of brain banks using transcriptomics and digital droplet PCR [14], both suggested a lack of association between human roseoloviruses and $\mathrm{AD}$.

Establishing a causal link between human roseoloviruses and $\mathrm{AD}$ is hindered by the high prevalence and chronicity of infection [21, 22]. The beta-herpesviruses demonstrate species-specific tropism, therefore in vivo studies of human roseoloviruses have been limited to immunodeficient humanized mice or transgenic mice expressing the receptor for HHV-6A, CD46 [23-25]. While these are useful models to study human roseoloviruses, there are clear restraints. The humanized mouse models are immunodeficient and infection is limited to transferred human cells, whereas the CD46 transgenic mouse models utilize intracranial infection and are limited to HHV-6A infection [23-25]. On the other hand, murine roseolovirus (MRV) is genetically and morphologically highly-related to the human roseoloviruses and likely has high prevalence in wild mouse populations [26-28]. Neonatal infection with MRV results in transient failure to gain weight, thymic atrophy and $\mathrm{CD}_{4}^{+} \mathrm{T}$ cell depletion $[26,29]$. We have previously shown that viral DNA was observed in the CNS after neonatal infection, although viral replication was not evaluated [26]. Furthermore, MRV DNA appeared to persist at low levels into adulthood, suggesting it establishes life-long latency similar to other herpesviruses.

Given the similarities of MRV to human roseoloviruses and its ability to infect the CNS, herein we investigated the impact of MRV on $A \beta$ accumulation in vivo using the 5XFAD mouse model that overexpresses human $A P P$ and PSEN1 transgenes with five AD-linked mutations [30]. We demonstrated that 5XFAD mice are susceptible to MRV infection and observed expression of late viral transcripts in the brain during acute infection, suggesting active viral replication. Additionally, we detected inflammation in the brain after peripheral and direct central nervous system (CNS) infection. Furthermore, $A \beta$ interacts with MRV particles in vitro and, subsequent to this interaction, can disrupt infection. Despite the presence of MRV in the brains of 5XFAD mice, we did not detect increased accumulation of $A \beta$ aggregates. Moreover, when we used RNA-sequencing (RNAseq) to evaluate a cohort of brains from Knight-ADRC research participants who either were cognitively unimpaired without $\mathrm{AD}$ or who had dementia due to $\mathrm{AD}$ at time of death, we found there was no association between HHV6 infection frequency and AD. Taken together, our data demonstrate that although MRV infects the brain and 
induces both an acute peripheral and central inflammatory response, MRV does not increase $A \beta$ aggregation in the brains of 5XFAD mice. Similarly, we found no association of HHV-6 RNA prevalence in AD human brains.

\section{Methods}

Animals

5XFAD (B6SJL-Tg (APPSwFlLon,PSEN1*M146L*L286V) 6799Vas/Mmjax) and B6SJLF1/J mice were purchased from Jackson Laboratories. BALB/c mice were purchased from Charles River Laboratories. Mice were bred in house under pathogen-free conditions. Mice that were MRV-infected were housed in separate cages from mock-infected mice to avoid horizontal transmission. For all neonatal infections, male and female mice were infected and included in the experiments (sex ratio overall was $\sim 50 \%$ ). For infection of adult mice, female mice were used for all studies. These studies were conducted in accordance with institutional ethics guidelines in place through institutional animal care and use committee (IACUC) protocols approved by the Animal Studies Committee of Washington University in St. Louis.

\section{Virus stock and infection}

MRV stocks were prepared from in vivo passaging in $\mathrm{BALB} / \mathrm{c}$ mice as described previously [26]. For peripheral infection, mice received intraperitoneal (i.p.) inoculation using a 30-guage needle with $50 \mu \mathrm{L}$ of a 1:5 dilution of viral stock in serum-free DMEM for a dose of $\sim 2 \times 10^{7}$ MRV genome copies. Mock infection was performed similarly with $50 \mu \mathrm{L}$ of serum-free DMEM.

For intracranial intrahippocampal injections, virus stock was semi-purified through a sorbitol cushion as described previously [31, 32], with several modifications. Briefly, MRV virus stocks were prepared from minced thymus. Cells were pelleted by centrifugation, then were lysed using a cup horn sonicator. Large cellular debris was pelleted by centrifugation and supernatant was removed and layered onto a $20 \%$ sorbitol cushion $(20 \%$ dsorbitol, $50 \mathrm{mM}$ Tris- $\mathrm{HCl}, \mathrm{pH} 7.2,1 \mathrm{mM} \mathrm{MgCl}_{2}$ ) at $55,000 \times \mathrm{g}$ for $1 \mathrm{~h}$ using an ultracentrifuge. The remaining pellet was resuspended in $1 \%$ fetal bovine serum (FBS) in DMEM or PBS. For intracranial infection with semipurified MRV stocks in 1\% (FBS), six-week-old 5XFAD received bilateral, intrahippocampal injections of MRV with a $5 \mu \mathrm{L}$ Hamilton syringe with a 30 -gauge needle attached to a Kopf stereotaxic instrument $\left(4 \times 10^{6} \mathrm{MRV}\right.$ genome copies; $2 \mu \mathrm{L} /$ site; AP: $-2.0, \mathrm{ML}:+1.6 /-1.6$, DV: $-2.0 ; 0.15 \mu \mathrm{L} / \mathrm{min}$ infusion rate). The needle was left undisturbed for 5 additional minutes after the injection before withdrawal. All mice were sacrificed $72 \mathrm{~h}$ post infection. To evaluate the impact of $\mathrm{A} \beta$ on infection, semi-purified viral stock in PBS was incubated with DMSO control or oligomeric- $\mathrm{A} \beta_{42}$ at a concentration of
$10 \mu \mathrm{M}$ for $2 \mathrm{~h}$, then diluted 1:5 in PBS and $50 \mu \mathrm{L}$ was injected intraperitoneally into postnatal day 0 (P0) $\mathrm{BALB} / \mathrm{c}$ mice.

\section{Nanogold-labeled $A \beta$ sample preparation}

Human $A \beta_{42}$ peptides (Cat\#: 107761-42-2, GenScript) were resuspended with $1 \mathrm{~mL}$ of 1,1,1,3,3,3-Hexafluoro-2propanol (HFIP). HFIP was then evaporated in a chemical hood overnight to obtain dry monomeric $A \beta_{42}$ layer that was stored at $-20^{\circ} \mathrm{C}$ in aliquots. On day of use, one $100 \mu \mathrm{g}$ aliquot was dissolved with $5 \mu \mathrm{L}$ of DMSO and diluted with sodium bicarbonate buffer $(\mathrm{pH}=8.0)$ to make $10 \mu \mathrm{M}$ monomeric $\mathrm{A} \beta_{42}$. Next, $10 \mathrm{nmol}$ of Mono-SulfoN-Hydroxy-Succinimido- Nanogold ${ }^{\bullet}$ Labeling Reagent (Cat\#: 2025, Nanoprobes) was added to the solution and incubated at RT overnight. Excess nanogold molecules were removed via three-day dialysis in $\mathrm{H}_{2} \mathrm{O}$ with $3.5 \mathrm{kDa}$ cut-off tube at $4{ }^{\circ} \mathrm{C}$. After dialysis, dry nanogold-labeled or unlabeled $A \beta_{42}$ was obtained after overnight speed vacuum centrifugation at RT. The nanogold-labeled $\mathrm{A} \beta_{42}$ was dissolved with $5 \mu \mathrm{L}$ of DMSO and used for preparation of monomeric, oligomeric $A \beta_{42}$ and $A \beta_{42}$ fibrils following a published protocol [33]. Briefly, oligomeric $A \beta_{42}$ was formed using $\mathrm{F} 12$ media at $4{ }^{\circ} \mathrm{C}$ and $\mathrm{A} \beta_{42}$ fibrils were formed in $10 \mathrm{mM} \mathrm{HCl}$ at $37^{\circ} \mathrm{C}$ for at least $24 \mathrm{~h}$.

\section{Negative staining transmission electron microscope (NS- TEM) imaging}

Before NS sample preparation, $10 \mu \mathrm{M}$ of monomeric, oligomeric and fibrillar nanogold-labeled $\mathrm{A} \beta_{42}$ was mixed with purified MRV samples and incubated for $2 \mathrm{~h}$. Afterwards, all NS samples were vortexed and prepared following standard uranyl formate negative staining protocol. At least 50 TEM images containing viral particles per sample were obtained with JEOL JEM-1400 120 $\mathrm{kV}$ TEM with 80,000x magnitude. The quantification of nanogold-labeled $A \beta_{42}$ interaction with MRV particles was conducted by a blinded reviewer scoring for nanogold negative or positive viral particles.

\section{Tissue harvesting \\ Perfusion}

Mice were anesthetized with Fatal-Plus (pentobarbital, $200 \mathrm{mg} / \mathrm{kg}$, intraperitoneal) and transcardially perfused for three minutes with chilled phosphate-buffered saline (PBS) solution containing 0.3\% heparin.

\section{Brain extraction}

Brains were hemisected: one hemisphere was dissected for specific brain regions, flash-frozen on dry ice, and stored at $-80^{\circ} \mathrm{C}$ for biochemical and gene transcript analyses; the other hemisphere was fixed in $4 \%$ 
paraformaldehyde for $24-48 \mathrm{~h}$ and cryoprotected in 30\% sucrose at $4{ }^{\circ} \mathrm{C}$ before sectioning for histology.

\section{Spleen and thymus collection}

Spleen and thymus dissection was performed as described previously [29]. Briefly, for nucleic acid analysis tissue was dissected and stored at $-80^{\circ} \mathrm{C}$ or prepared for flow cytometry as described below.

\section{Histology and quantification Sectioning}

Hemibrains were sectioned coronally at $50 \mu \mathrm{m}$ into six series using a freezing, sliding microtome (Leica). Brain slices were then stored at $-20{ }^{\circ} \mathrm{C}$ in cryoprotectant solution (0.2 M PBS, $15 \%$ sucrose, 33\% ethylene glycol) until use. All histological studies were conducted by staining for two to three tissue slices from each mouse, separated by $300 \mu \mathrm{m}$ (bregma $-1.5,-1.8$, and $-2.1 \mathrm{~mm}$ or -1.8 , and $-2.1 \mathrm{~mm})$.

\section{Immunostaining with $D A B$}

Brain tissue staining was performed at room temperature and on a shaker as previously described [34]. Briefly, tissue sections were rinsed 3 times for 5 min each with Tris-buffered saline (TBS) and then blocked for nonspecific binding with 3\% milk in TBS containing $0.25 \%$ Triton-X100 (TBS-X) for $30 \mathrm{~min}$. Sections were then incubated at $4{ }^{\circ} \mathrm{C}$ overnight using primary antibodies (biotinylated anti- $\mathrm{A} \beta_{1-13}$ monoclonal antibody HJ3.4B (produced in-house, $2 \mu \mathrm{g} / \mathrm{mL}$ ) for $\mathrm{A} \beta$, mouse monoclonal anti-tau (gift from L. Binder, Northwestern University, 1:500) for Tau5, mouse monoclonal anti-phospho-tau Ser202, Thr205 (Thermo Fisher Scientific, 1:500) for AT8 phosphorylated tau, and rabbit antiIba1 (Wako, 019-19,741, 1:5000) for microglia with biotinylated goat anti-rabbit IgG secondary antibody (Thermo Fisher Scientific, 31,820, 1:1000). The following day, tissue sections were rinsed 3 times for 5 min each with TBS and incubated for $1 \mathrm{~h}$ in VectaStain Elite ABCHRP Kit, Peroxidase (Vector Laboratories, PK-6100) and developed with DAB Eqv Peroxidase (HRP) Substrate (Vector Laboratories, SK-4103) following the manufacturer protocols. Glass slides were cover-slipped with cytoseal60 and allowed to air dry at room temperature for at least $24 \mathrm{~h}$. Stained brain sections were scanned using a Nanozoomer 2.0-HT slide scanner (Hamamastu Photonics) at 20X magnification, courtesy of the Hope Center Alafi Neuroimaging Core.

\section{Quantification}

Images were quantified using Fiji software version $1.52 \mathrm{v}$ (ImageJ). The percent area covered by immunostaining was calculated by setting a single threshold per staining experiment to traced cortical and hippocampal regions.
Two to three brain sections per mouse were averaged for an individual biological replica.

\section{Tissue lysate extraction and ELISA Brain homogenization}

Mouse posterior cortices were first homogenized in chilled PBS containing Complete Protease Inhibitor and phosSTOP Phosphatase Inhibitor ("Soluble fraction"), and then in $5 \mathrm{M}$ guanidine-HCL buffer, pH 8.0 ("Insoluble fraction") using magnetic beads (Next Advance, Bullet Blender Storm 24).

\section{Elisa}

ELISAs were performed using 96-well, half-well plates and concentrations were normalized to brain tissue weight. All antibodies were made in-house: anti- $\mathrm{A} \beta_{35-40}$ HJ2 (capture antibody for $\mathrm{A} \beta_{40}$ ), anti-A $\beta_{37-42}$ HJ7.4 (capture antibody for $A \beta_{42}$ ), biotinylated anti- $A \beta_{13-18}$ $\mathrm{HJ} 5.1 \mathrm{~B}$ (detection antibody for $A \beta_{40}$ and $A \beta_{42}$ ). $A \beta$ sandwich ELISAs were performed as previously described and concentrations were measured using Gen5 software version 1.11 with Synergy 2 (BioTek) [35] Samples were loaded in duplicates, averaged per mouse for an individual biological replicate.

\section{Nucleic acid preparation and analysis}

DNA was extracted from organs using the QIAamp DNA Mini Kit (Qiagen) while RNA was extracted from organs using the RNeasy Plus Kit (Qiagen) per manufacturer protocols. qPCR of DNA was performed using TaqMan Universal Master Mix II (Applied Biosystems). RNA was treated with DNase prior to being analyzed by qPCR using TaqMan RNA-to $C_{\mathrm{T}}$ 1-Step Kit (Applied Biosystems). qPCR was analyzed on a StepOnePlus real time PCR machine (Applied Biosystems). For MRV ORF69 standard curves were created using a plasmid of known base pairs in order to calculate copies/mL. For all other, relative expression compared to Actb (beta-actin) was calculated using $\Delta \Delta \mathrm{Ct}$. Primers used included: ORF69, Actb, IL-6, Iba1, ApoE, IL-1b, TREM2, GFAP.

\section{Flow cytometry}

Spleen and thymus were prepared for flow cytometry by first crushing through a $70-\mu \mathrm{m}$ cell strainer to obtain single cell suspensions. Red blood cells were lysed then cells were counted on a hemocytometer. Cells were stained with fixable viability dye (eBioscience) then incubated with 2.4G hybridoma supernatant to block Fc receptors. Surface staining was performed with the following fluorescent labeled antibodies: anti-CD3 $\varepsilon$ (1452C11), anti-CD4 (RM4-5), anti-CD8 $\alpha$ (53-6.7), and anti-CD44 (IM7) from Fisher Scientific, anti-CD19 (6D5), anti-NKp46 (29A1.4) and anti-CD62L (MEL-14) from Biolegend, and anti-CD45.2 (104) from 
eBioscience. Flow cytometry was performed on a FACS Canto (BD Biosciences) and analyzed using FlowJo v10 (TreeStar, Ashland, OR).

\section{RNA-seq data pre-processing}

Human parietal RNA-seq was generated from the Charles F. and Joanne Knight Alzheimer's Disease Research Center (Knight-ADRC) participants in two batches using Ribo-zero $150 \times 2$ pair-end reads. A detailed description of the sample selection criteria, extracted brain tissues, and the pipeline used for preprocessing and analyzing the human bulk RNA-seq data from this cohort is described elsewhere [36-39]. For this study, we used a subset of samples that are either definitive AD or controls. Precisely, the subset of samples retrieved from the Knight-ADRC consisted of 350 samples diagnosed with $\mathrm{AD}$ and 31 healthy controls. The obtained sequence files were in .bam format and already mapped to GENCODE [40] annotated human reference genome (GRCh38) using STAR software [41] in chimeric read detection mode. Unaligned reads from these aligned bam files were extracted using the "view - $\mathrm{b}-\mathrm{f} 4$ " command supported in the samtools suite (http:// samtools.sourceforge.net/). An unmapped BAM (uBAM) was created including these reads by using the "RevertSam" command supported in the picard tool suite (https://broadinstitute.github.io/picard/).

\section{Viral screening using RNA-seq data}

The unaligned RNA-seq reads (uBAM) files were screened for a collection of microbes including HHV-6A and HHV-6B by using the "PathSeq" tool developed by the BROAD Institute (http://software.broadinstitute.org/ pathseq/), using the pre-built microbe reference files (pathseq_microbe.fa.img). The total number of microbes screened for observing their abundance in the selected RNA-seq samples was 25,799 together with 118 human viruses. We used the "PathSeqPipelineSpark" command supported in the gatk tool suite (https://software. broadinstitute.org/gatk/download/) for running the "PathSeq" tool. The command was executed with default parameters (https://gatkforums.broadinstitute.org/gatk/ discussion/10913/how-to-run-the-pathseq-pipeline) and required pre-built references were downloaded from the BROAD Institute (https://software.broadinstitute.org/ gatk/download/bundle). The virus detection scores per individual sequence file output from the "PathSeq" tool were then imported into R (https://cran.r-proiect.org/), collated by cohort and virus types, visually inspected and plotted using "ggplot2" R package (version 3.3.3) [42].

\section{Statistical analysis of PathSeq results}

Based on the number of samples that were positive and negative for HHV-6A and HHV-6B, two vectors were produced containing normalized viral abundance scores, and a non-parametric Wilcoxon Rank Sum test [43] was performed to determine if there was any relationship between viral abundance and AD classification. The Wilcoxon Rank Sum test implementation in the base $R$ packages (version 3.5.2) [44] was used for this purpose.

\section{Statistical analysis}

Figures 1, 2, 3, 4, Supplementary Figs. 1, 2, 3: GraphPad Prism 8.0.2 was used to perform statistical analyses. Data are presented as means \pm SD/SEM. No other statistical comparisons were significant unless otherwise indicated. For two groups: Statistical significance with normally distributed data was performed using a Student's t-test (two-tailed). For data with unequal standard deviations, a t-test with Welch's correction was performed. For three or more groups: Gaussian distribution of data was checked with the Anderson-Darling, D'Agostino and Pearson, and Shapiro-Wilk normality tests. One-way analysis of variance (ANOVA) followed by Tukey's post hoc test was used to determine statistical significance. Asterisks represent $P$ values as follows: ${ }^{*}=P<0.05$, ${ }^{* * *}=$ $P<0.01$, $^{* * * *}=P<0.001$, **** $=P<0.0001$.

\section{Results}

\section{XFAD mice are susceptible to MRV infection and} develop neuroinflammation

We previously demonstrated that neonatal, peripheral MRV infection of BALB/c and C57BL/6 wild-type (WT) mice resulted in MRV DNA in the CNS, depletion of CD4 single positive (SP) and CD4CD8 double positive (DP) thymocytes, $\mathrm{CD}_{4}^{+} \mathrm{T}$ cells in the periphery, and peripheral inflammation as measured by an increase in activated $\mathrm{CD}^{+} \mathrm{T}$ cells $[26,29]$. To examine the consequences of MRV infection in 5XFAD mice, we first investigated whether MRV infects the brains of neonatal 5XFAD mice after peripheral infection using intraperitoneal (i.p.) injection (Fig. 1a). We evaluated MRV DNA in the brains of 5XFAD mice compared to WT B6.SJL mice at 7 days post infection (dpi) and found similar levels in the cortex (Fig. 1b). Studies of herpesviruses have demonstrated that expression of late viral transcripts is correlated with viral replication [45]. We therefore utilized expression of the putative late viral transcript, ORF69, as a proxy of viral replication and found similar levels of expression in 5XFAD and WT mice (Fig. 1c). We then tested whether 5XFAD mice are susceptible to $\mathrm{CD} 4^{+}$ thymocyte and peripheral $\mathrm{CD} 4^{+} \mathrm{T}$ cell depletion after neonatal MRV infection. Indeed, we determined that 5XFAD mice develop depletion of CD4 SP and DP thymocytes as well as $\mathrm{CD}^{+} \mathrm{T}$ cell depletion and an increase in activated $\mathrm{CD}^{+} \mathrm{T}$ cells in the periphery (Fig. 1d, e). Finally, since our data suggested active MRV replication in the brain, we evaluated expression of multiple 

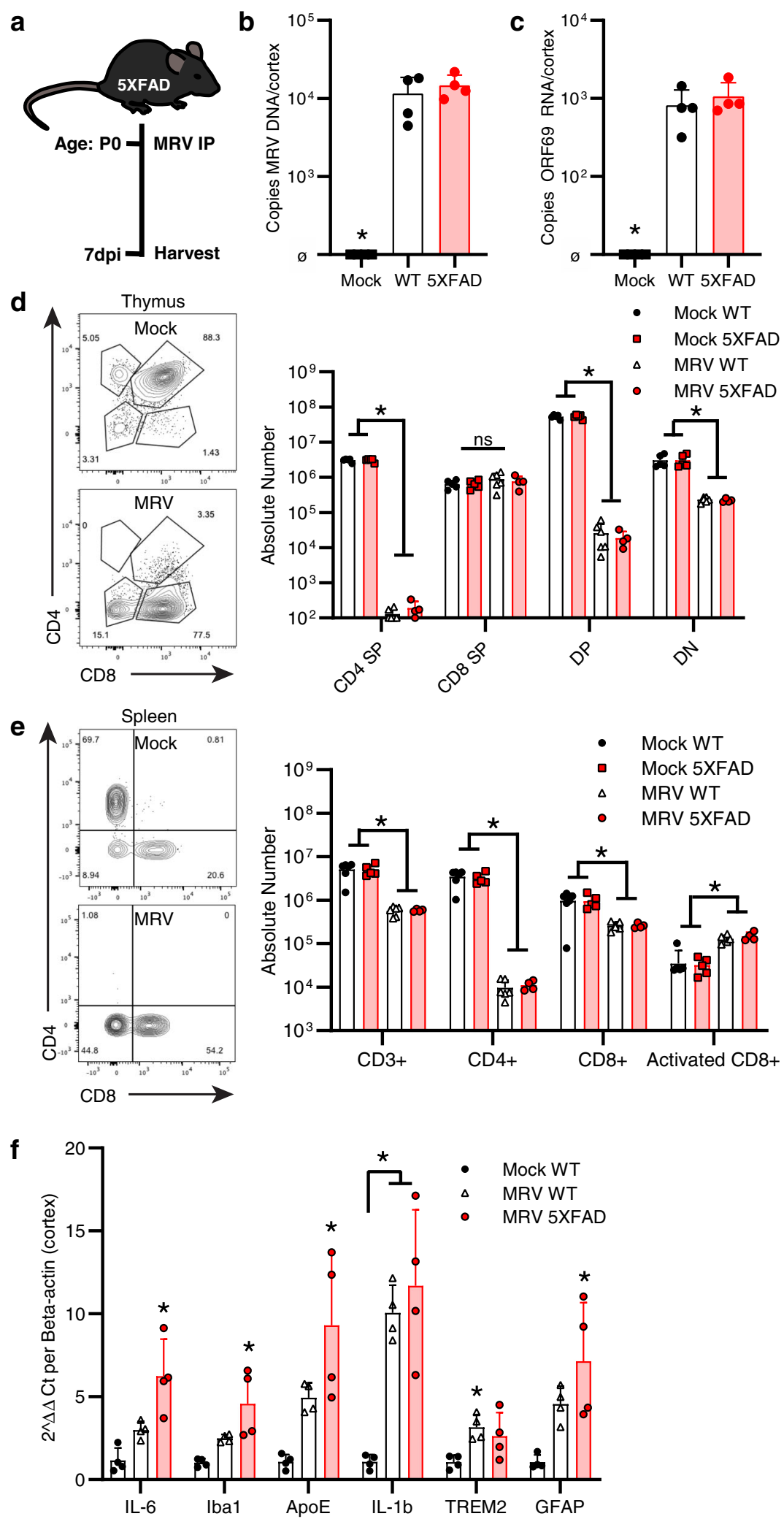

Fig. 1 (See legend on next page.) 
(See figure on previous page.)

Fig. 1 MRV infects the CNS and elicits a peripheral and central inflammatory response in 5XFAD mice. A Schematic of experimental paradigm. B, C, Copies/mL of MRV DNA B and ORF69 RNA C in cortex of 5XFAD mice infected with mock or MRV 7 dpi (i.p.). D, E, Flow cytometry of absolute number of $\mathrm{CD}_{4} 5^{+} \mathrm{CD} 19^{-} \mathrm{NKp} 46^{-} \mathrm{CD}^{+}$or $\mathrm{CD} 8^{+}$thymocytes $\mathbf{D}$ and $\mathrm{CD} 45^{+} \mathrm{CD} 19^{-} \mathrm{NKp} 46^{-} \mathrm{CD}^{+} \mathrm{CD}^{+}$or $\mathrm{CD} 8^{+} \mathrm{T}$ cells in the spleen $\mathbf{E}$. $\mathbf{F}$ Inflammatory gene expression changes in cortical tissue. ${ }^{*} P<0.05$ between WT mock and 5XFAD MRV. DP: $C D 4^{+} C D 8^{+}$double positive. DN: $\mathrm{CD}^{-}{ }^{-} \mathrm{CD} 8^{-}$double negative. $\varnothing$ represents below levels of detection. Dpi: days post infection. Data expressed as mean $\pm \mathrm{SD}$, one-way ANOVA with Tukey's post hoc test (two-sided) (b, c, d, e, f). $P<0.05$. ns = not statistically significant. No other statistical comparisons are significant unless indicated

inflammatory genes from the cortex of infected 5XFAD and WT mice compared to uninfected WT mice. We detected an increase in certain transcripts for microglia (Iba1), disease-associated microglia (Trem2), diseaseassociated astrocytes (Gfap), and proinflammatory cytokines $(I l 6, I l-1 b)$ (Fig. 1f) [46, 47].. Together, these data demonstrate 5XFAD mice are equally susceptible to MRV infection as WT mice, with functional peripheral effects ( $\mathrm{T}$ cell depletion) and viral replication in the brain inducing increased expression of inflammatory genes.

\section{$A \beta$ interacts with MRV particles in vitro and disrupts infection in vivo}

Studies proposing $A \beta$ as an antimicrobial peptide are predicated on the findings that, like other antimicrobial peptides, $A \beta$ interacts with pathogens to disrupt infection $[2-4,48]$. Furthermore, $A \beta$ has been demonstrated to interact with herpesvirus particles, including HHV-6, and inhibit HSV infection in vitro $[3,5]$. We therefore evaluated $A \beta$ interactions with MRV. We generated monomeric, oligomeric or fibrillar $A \beta_{42}$ in a $10 \mu \mathrm{M}$ suspension to differentiate which form of $A \beta_{42}$ may interact with MRV particles from purified viral stocks. We incubated viral particles with $A \beta_{42}$ for $2 \mathrm{~h}$, then used negative staining transmission electron microscopy (NS-TEM) to identify nanogold-labeled $\mathrm{A} \beta(>1.4 \mathrm{~nm})$. We found that compared to PBS (Blank) and nanogold controls, all forms of $A \beta_{42}$ interacted with viral particles (Fig. 2a). This was true for the majority of viral particles imaged, although the percent of interaction was lowest for monomeric $A \beta_{42}$ (Fig. 2b). Interestingly, in general there were no large aggregates of $A \beta_{42}$ associated with viral particles, nor was there direct interaction of $A \beta_{42}$ fibrils with viral particles even though the monomers/oligomers in the suspension did interact (Fig. 2a). Our data does not differentiate if the nanogold-labeled $A \beta$ interacting with MRV particles in the oligomeric and fibrillar $\mathrm{A} \beta_{42}$ preparations was oligomeric or monomeric. Although we did not observe MRV interactions with large $\mathrm{A} \beta_{42}$ aggregates as previously reported [5], these data demonstrate that MRV does interact with certain forms of $A \beta_{42}$ in vitro.

We next evaluated whether $A \beta_{42}$ has antimicrobial properties against MRV. Inhibitory properties of antimicrobial peptides, including $A \beta_{42}$, were suggested to be associated with $A \beta$ oligomerization, which is the preparation of $A \beta_{42}$ we observed to have the highest percentage of interaction with MRV (Fig. 2b) [2, 5, 49-51]. We therefore tested the impact of oligomeric- $A \beta_{42}$ on MRV infection. Purified viral stock was incubated with $10 \mu \mathrm{M}$ purified oligomeric- $\mathrm{A} \beta_{42}$ for $2 \mathrm{~h}$, then BALB/c mice were infected on postnatal day 0 (P0). We observed that compared to control infection, oligomeric- $A \beta_{42}$ incubation with MRV resulted in a marked reduction in CD4 SP and DP depletion as well as a reduction in MRV DNA in the thymus (Fig. 2c, d). These findings confirm that $A \beta_{42}$ interacts with MRV particles in vitro and then subsequently disrupts MRV infection in vivo.

\section{MRV infection does not increase cortical $A \beta$ deposition of 5XFAD mice after peripheral infection}

Human roseoloviruses infections typically occur in childhood and demonstrate high seroprevalence in adulthood [21]. The impact and incidence of reinfection and frequency of reactivation of roseoloviruses is unknown, including for MRV. We therefore took several different approaches to evaluate the influence of MRV infection on the development of $A \beta$ load. Because human roseoloviruses infections typically occur early in life, we performed neonatal i.p. infection of P0 neonatal 5XFAD mice and assessed $A \beta$ load at 6 months (Fig. S1a). While we observed that the percentage of peripheral $\mathrm{CD} 4^{+} \mathrm{T}$ cell per total $\mathrm{T}$ cells was decreased at $10 \mathrm{dpi}$ (Fig. S1b) similar to what we have published previously in other mouse strains [26, 29], this effect was transient and no longer present at 6 months post infection (mpi) (Fig. S1c). Importantly, we did not observe a change in $A \beta$ plaque load in the cortex $6 \mathrm{mpi}$ after neonatal MRV infection (Fig. S1d, e). Since accumulation of tau can also be pathogenic, we evaluated immunostaining for total tau and phosphorylated tau (p-tau) levels in mock and MRV infected mice and did not observe increased levels of either after MRV infection (Fig. S1f-i). One possibility for the absence of an effect of MRV on $A \beta$ plaque load could be explained by a saturation effect of $A \beta$ by 6 months of age. We therefore tested whether neonatal MRV infection could accelerate the seeding of $A \beta$ plaques in 6-week-old 5XFAD mice, a timepoint before the formation of extracellular $A \beta$ plaques (Fig. S1j) [30]. 


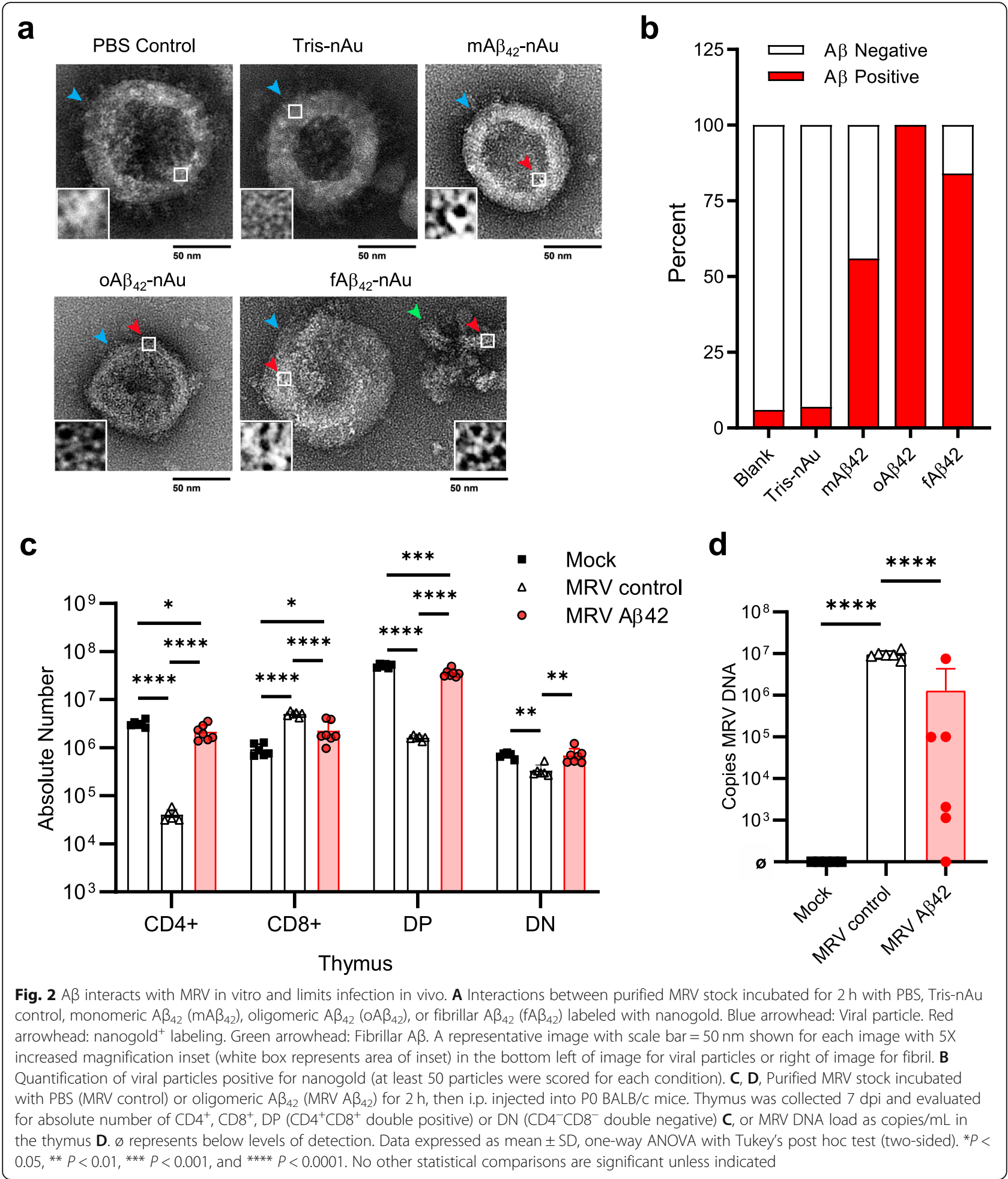

After neonatal i.p. infection, we did not detect a difference in $A \beta$ immunoreactivity in the cortex of mock- and MRV-infected mice (Fig. S1k, l). These findings suggest that neonatal MRV infection did not facilitate $A \beta$ deposition when assessed at two timepoints (pre- and post-plaque).

Extracellular $\mathrm{A} \beta$ plaque formation begins at around 8 weeks in 5XFAD mice in the cortex [30]. It may be 


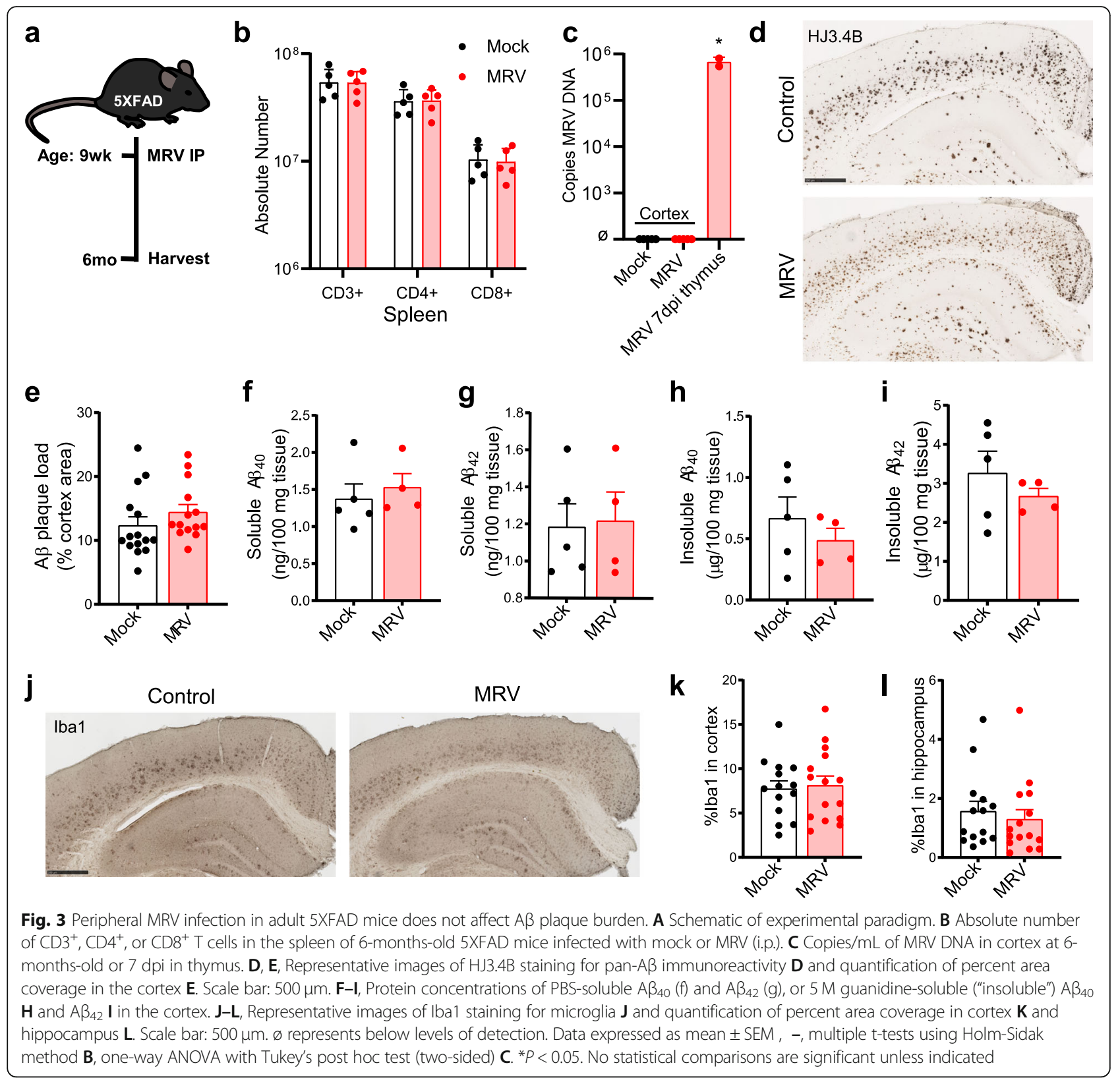

possible that pre-existing plaques in conjunction with viral infection are required to trigger downstream neuropathogenesis. We therefore also performed i.p. infections at 9 weeks, after the onset of plaque formation, and evaluated $A \beta$ plaque load at $3 \mathrm{mpi}$, at 6 months of age, a timepoint characterized by high $\mathrm{A} \beta$ plaque burden (Fig. $3 a)$. Although we previously observed $\mathrm{CD}^{+} \mathrm{T}$ cell depletion at $10 \mathrm{dpi}$, we did not observe prolonged $\mathrm{CD} 4^{+} \mathrm{T}$ cell depletion in the periphery or significant levels of MRV DNA in the cortex of 5XFAD mice at $3 \mathrm{mpi}$ (Fig. 3b, c). Moreover, there was no change in cortical $A \beta$ plaque pathology between mock- and MRV-infected mice when assessed using two methodological approaches, histology and enzyme-linked immunosorbent assay (ELISA) (Fig.
$3 \mathrm{~d}-\mathrm{i})$. Similarly, there was no difference in $\mathrm{Iba}^{+}$microglial coverage in the cortex and hippocampus of mockand MRV-infected mice (Fig. 3j-l). These results suggest that adult MRV infection does not facilitate A $\beta$ progression and formation in a mouse model of amyloidosis. Taken together, these data suggest that peripheral infection with MRV did not accelerate or increase $A \beta$ formation in 5XFAD mice, despite an acute inflammatory response in the CNS and periphery.

\section{Adult CNS infection with MRV results in acute inflammation but does not increase $A \beta$ load}

One possible explanation for the discrepancy between our findings and previous work on the effects of viral 


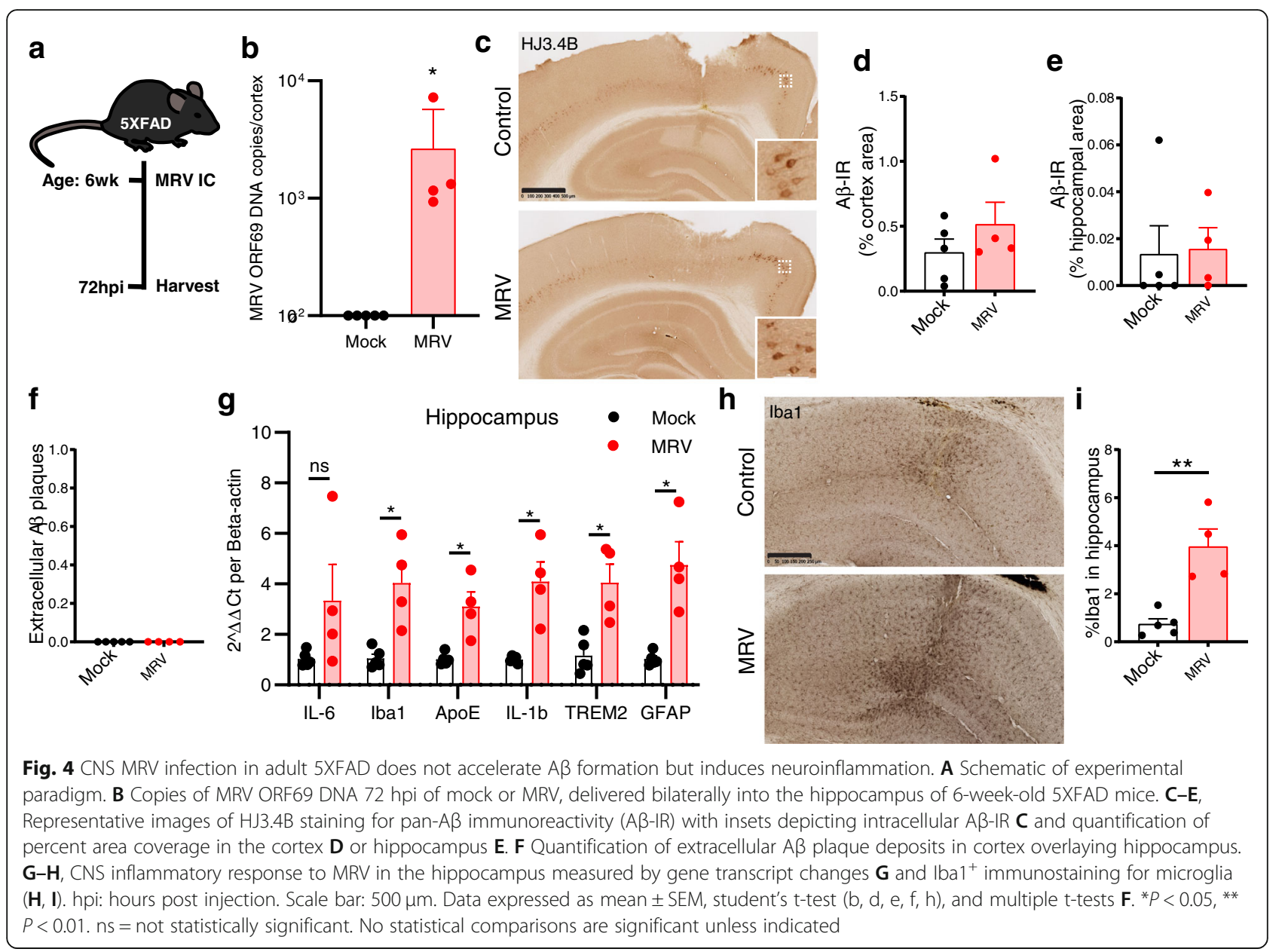

pathogens on $A \beta$ deposition could conceivably be differences in the route of infection [5]. One study that demonstrated enhanced $A \beta$ aggregation in 6-week-old mice after HSV-1 infection was performed using direct, intracranial hippocampal infection [5]. Therefore, we performed a similar experiment in which we injected MRV $\left(4 \times 10^{6}\right.$ genome copies of virus stock) bilaterally into the hippocampus and evaluated $A \beta$ load $72 \mathrm{~h}$ post infection (hpi) (Fig. 4a). We used a semi-purified viral stock, which showed similar infection characteristics compared to unpurified stocks, to reduce any impact of non-viral components on $A \beta$ load and inflammation (Fig. S2). We detected MRV DNA in the hippocampus of all infected mice (Fig. 4b). However, we detected no change in $A \beta$ immunoreactivity in the hippocampus and cortex (Fig. $4 \mathrm{c}-\mathrm{e}$ ), or formation of extracellular $\mathrm{A} \beta$ plaques (Fig. 4f). Similar to neonatal, peripheral infections, MRV intracranial infection stimulated an acute, inflammatory response marked by an upregulation in microglial, astrocytic, and pro-inflammatory cytokine-related gene transcripts (Fig. 4g). These data were supported by an increase in $\mathrm{Iba}^{+}$microglial coverage in the hippocampus of MRV-infected brains (Fig. 4h, i). There was also an increase in total tau immunoreactivity in the cortex (Fig. S3a-c), which was potentially a response to focal inflammation [52-54]. There was not a statistically significant increase in total tau immunoreactivity in the hippocampus or phosphorylated tau in the cortex or hippocampus (Fig. S3e-g). Our findings suggest that MRV can induce inflammation in the brain after direct CNS infection, but neither MRV nor inflammation secondary to infection are sufficient to rapidly increase $A \beta$ deposition in the brain.

\section{HHV-6 abundance is similar between human AD and control brains}

RNAseq data from the Knight-ADRC cohort was available from frozen brain parietal cortex tissue for 381 individuals. Only a subset of the Knight-ADRC cohort was considered for this study where clinical data for each individual included Clinical Dementia Rating (CDR) score at the time of death and neuropathological assessment (Table 1). We performed RNA-seq analysis similar to previously described studies [36-39], aligning reads to the human genome followed by alignment of unmatched reads to 25,799 pathogens, including 118 human viruses 
Table 1 Demographics of RNAseq samples from Knight-ADRC cohort. Abbreviations: SD, standard deviation; APOE4+, apolipoprotein E4 carriers; CDRe, Clinical Dementia Rating at death; Braak DLB, Braak stages for dementia Lewy body; PMI, postmortem interval in hours; AD, Alzheimer's disease; $C O$, controls; $A A O$, age at disease onset in years; AOD, Age of death in years

\begin{tabular}{|c|c|c|c|c|c|c|c|c|c|}
\hline \multicolumn{2}{|c|}{ Diagnosis } & Sex & \multicolumn{2}{|c|}{ Age, mean (sd) } & APOE4+ & $\begin{array}{c}\text { CDRe, } \\
\text { mean (sd) }\end{array}$ & $\begin{array}{l}\text { Braak Tau, } \\
\text { mean (sd) }\end{array}$ & $\begin{array}{l}\text { Braak DLB, } \\
\text { mean (sd) }\end{array}$ & $\begin{array}{l}\text { PMI, mean } \\
\text { (sd) }\end{array}$ \\
\hline Type & No. & Female, No. (\%) & AAO & AOD & (\%) & & & & \\
\hline$A D$ & 350 & $204(58.29)$ & $\begin{array}{c}73.55 \\
(11.14)\end{array}$ & $\begin{array}{c}81.37 \\
(12.14)\end{array}$ & 56 & $2.53(0.83)$ & $5.2(1.15)$ & $4.54(1.84)$ & $12.62(6.87)$ \\
\hline $\mathrm{CO}$ & 31 & $20(64.52)$ & $\begin{array}{c}79.88 \\
(13.07)\end{array}$ & $\begin{array}{l}87.68 \\
(9.49)\end{array}$ & 6.45 & $0.32(0.76)$ & $2.26(1.07)$ & $2(0)$ & $10.14(5.62)$ \\
\hline
\end{tabular}

[19]. Identification of HHV-6 transcripts was rare in non-AD control and AD samples (HHV-6A: 1/31 in non-AD controls and 2/350 in AD; HHV-6B: 1/31 in non-AD controls and $3 / 350$ in AD) (Fig. 5a). HHV-7 transcripts were not identified in either the non-AD or AD samples. Upon arranging individuals based on their PathSeq scores, we observed no clear distinction of viral abundance between the individuals with AD vs. the controls (Fig. 5b). The normalized PathSeq score was based on the number of reads that align with a references taxon and indicates the amount of evidence that a taxon is present in a particular individual [44]. Moreover, upon checking the relationship between viral abundance and AD classification using the non-parametric Wilcoxon Rank Sum test, we observed no significant difference for either HHV-6A $(P$-value $=0.11)$ or HHV-6B $(P$-value = 0.22 ) between $\mathrm{AD}$ and controls groups (Fig. 5a). Therefore, our data, similar to a recent study [14], does not support an association between human roseolovirus infection and $\mathrm{AD}$ in the analysis of this cohort.

\section{Discussion}

The relationship between the human roseoloviruses and $\mathrm{AD}$ has been of significant recent interest. While several studies have reported an association between HHV-6 or HHV-7 and AD [6, 17-19, 55], others have provided data that there is not a relationship [14, 20, 56, 57]. Currently, mouse models of human HHV-6 are limited. MRV is a natural murine pathogen and is highly related to $\mathrm{HHV}-6$ and $\mathrm{HHV}-7$, sharing genetic, morphologic and disease homology [26]. Moreover, our studies demonstrate that MRV enters the CNS and replicates in the cortex. Studying MRV therefore affords an opportunity to perform in vivo studies to model human roseolovirus neuropathogenesis, especially its relation to neuropathological features of AD-like disease in mice.

The antimicrobial protection hypothesis of $A \beta$ posits that pathogens causing persistent or recurrent infections in the $\mathrm{CNS}$ are sequestered by $\mathrm{A} \beta$, triggering a hyperreactive innate immune response that results in $A \beta$ fibrillization and consequently contributes to $\mathrm{AD}$ [50]. Indeed, we found that purified $A \beta_{42}$ interacted with $M R V$ particles in vitro and, subsequent to this interaction, disrupted infection in vivo. We therefore evaluated $A \beta$ deposition after MRV infection to test the antimicrobial hypothesis for MRV infection. Natural infection with MRV likely occurs through secretions [58], but i.p. infection would similarly require MRV to enter the CNS from the periphery, which we found did indeed occur after neonatal infection. However, in our studies, we did not observe an increase in $A \beta$ after MRV infection of 5XFAD mice. It is important to note that, similar to other recent studies $[5,59]$, we focused on expression of human transgenic $A \beta$ and did not evaluate endogenous mouse APP expression, which has been suggested to have antimicrobial properties [4]. Factors such as the impact of MRV infection on APP expression driven by the endogenous mouse promoter compared to the Thy1 promoter remain to be explored. We approached investigating the impact of infection in multiple ways, including utilizing two routes of infection (peripheral, i.p. or direct $\mathrm{CNS}$, intracranial), infecting at various timepoints (pre- or post-A $\beta$ plaque development), as well as multi-timepoint assessments post-infection (acute or chronic). None of these scenarios resulted in increased A $\beta$ load, suggesting that MRV does not facilitate the progression of $A \beta$ accumulation over time.

Eimer et al. demonstrated that high dose intracranial $\mathrm{HSV}-1$ infection in 5XFAD mice induced $\mathrm{A} \beta$ plaque formation by $72 \mathrm{~h}$ in 6-week-old-mice, with colocalization of A $\beta$ plaques with $\mathrm{HSV}-1$ viral particles [5]. A subsequent study that attempted to repeat these results with defined HSV-1 strains, albeit with potentially lower multiplicity of infection, did not observe colocalization of HSV-1 and A $\beta$ plaques [60]. Neither study quantified the $A \beta$ plaque load after infection, an important analysis given the rapid plaque formation reported in the former study. We therefore performed similar intracranial infections of 6-week-old 5XFAD mice with MRV and did not observe extracellular $A \beta$ plaque formation. A caveat of these studies is intracranial injection was not performed at a later time point when $A \beta$ plaques have begun to accumulate, which conceivably could be further seeded by a virus. Our studies were limited by the current lack of 
a Knight-ADRC

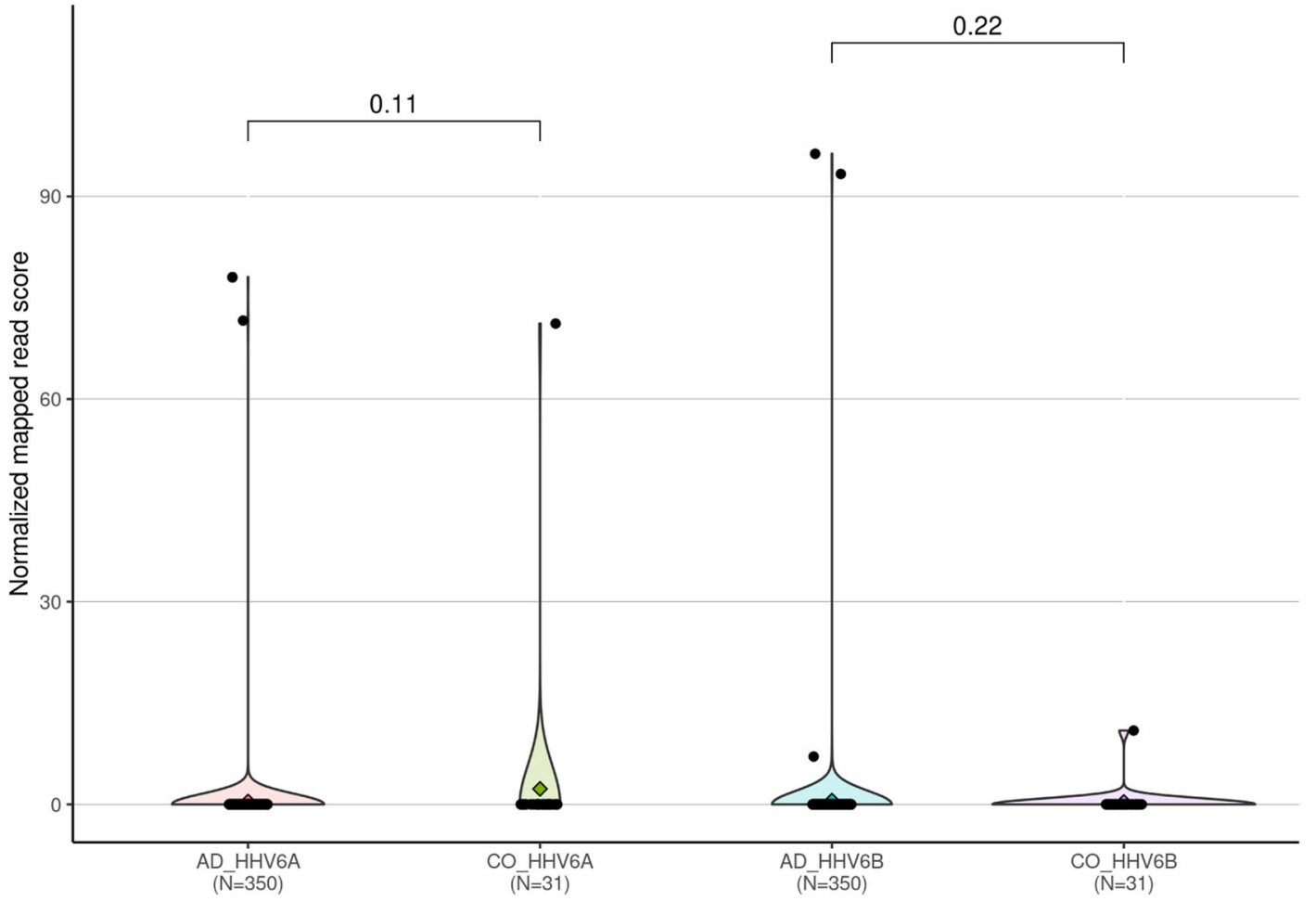

b Knight-ADRC

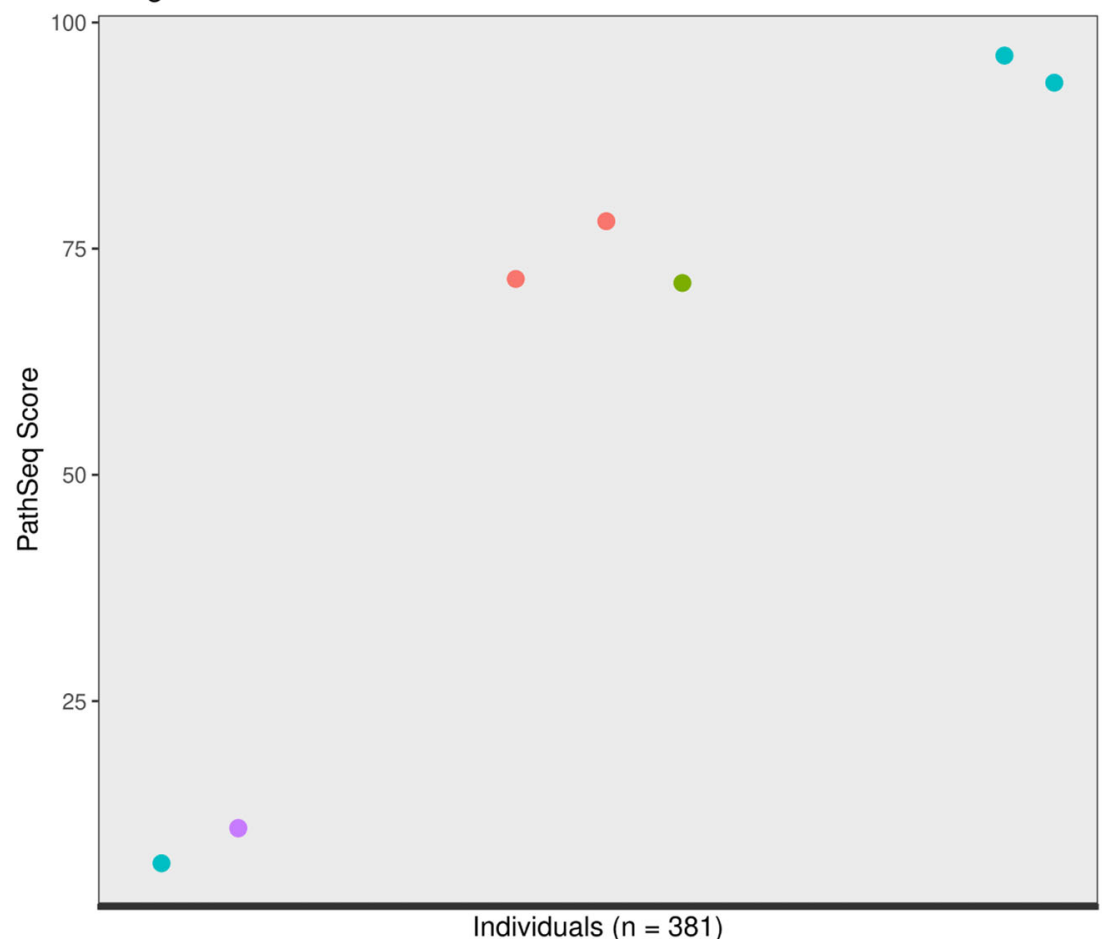

- AD_HHV6A

- CO_HHVGA

- AD HHV6B

CO HHVGB

Individuals $(\mathrm{n}=381$ )

Fig. 5 (See legend on next page.) 
(See figure on previous page.)

Fig. 5 Relationship between viral abundance and AD status. A Comparisons of HHV-6A and -6B viral abundance between $A D(N=350)$ and nondemented controls $(N=31)$ in the Knight-ADRC cohort. Diamonds in violin plot: mean of group. Shape of violin plot: distribution of normalized PathSeq scores across each group. The $p$-values representing the significance of difference between the viral abundance in AD and controls groups for HHV-6A and -6B are shown at the top of corresponding violin plots. The $p$-values were obtained by performing a non-parametric Wilcoxon Rank Sum test in order to determine if there was any relationship between viral abundance and AD classification. Abbreviations: $A D$, Alzheimer Disease; CO, controls; HHV, human herpes virus. B Abundance of HHV-6A and HHV-6B in Knight-ADRC. HHV-6A and HHV-6B normalized PathSeq scores displayed in an increasing order for all the samples (AD and controls) in the Knight-ADRC cohort. Normalized PathSeq score based on the number of reads that align with a references taxon and indicates the amount of evidence that a taxon is present in a

particular individual

tools available to evaluate localization of MRV in tissues such as MRV-specific antibodies. Although we cannot compare doses between MRV and HSV-1, we cannot rule out that higher doses of MRV could induce $A \beta$ formation.

The association between $\mathrm{AD}$ and human roseolovirus has been the focus of numerous multi-omics studies. A study of multiple cohorts utilizing genomic, transcriptomic and proteomic data reported an association between $\mathrm{AD}$ and human roseoloviruses, especially HHV6A and HHV-7 [19]. Furthermore, the data suggested that certain pathways associated with inflammation and viral immune response were differentially expressed in $\mathrm{AD}$ patients compared to non-AD controls. Two subsequent studies have called these findings into question. One study performing a reanalysis of the data with different statistical methods showed no difference [20]. An additional study of three AD cohorts using RNAseq and digital droplet PCR analysis did not establish differences in human roseolovirus detection between $\mathrm{AD}$ and control samples $[14,20]$. Similar to the study by Allnut, et al., we did not identify an association between human roseoloviruses and $\mathrm{AD}$ in our RNAseq analysis of the Knight-ADRC cohort. HHV-6A and HHV-6B were only detected in a few patients in both the AD and non-AD control samples. Moreover, given the small number of positive patients, we could not establish a statistically significant PathSeq score between the $\mathrm{AD}$ and non-AD groups. Although our data do not rule out a potential contribution of human roseoloviruses in the pathogenesis of AD, especially at an individual level, it does support recent data suggesting that roseoloviruses are not associated with $\mathrm{AD}$ at the population level.

Although herpesviruses have garnered interest as causative contributors to development of $\mathrm{AD}$ due to their neurotropism and chronic infections with periodic reactivation, utilizing -omics analysis from a single time point does not allow for evaluation of the viral load during, and frequency of reactivation. Moreover, selectively sampling CNS tissue at times of reactivation is not possible under most circumstances in human subjects. Several recent studies have suggested that treatment with antivirals for herpesvirus infections was associated with a decreased risk of dementia later in life compared to untreated patients [61-64]. In these studies, treatment generally was given in relatively short intervals considering the lifelong nature of herpesvirus infections, and many patients were treated with acyclovir, which has low efficacy against HHV-6 [65-67]. Prospective randomized control trials will likely address the use of herpes-specific antivirals for $\mathrm{AD}$, although studying the impact of antiviral on reactivation in mice could provide a means to test efficacy in vivo. Indeed, a recent study using thermal stress to serially reactivate HSV-1 in mice demonstrated that intermittent stress resulted in HSV-1 reactivation, inflammation, and increased $A \beta$ deposition in the brain [59]. While MRV reactivation has not been examined in detail, it is possible that MRV also requires induced reactivation through intermittent stress to promote $A \beta$ accumulation. Additionally, reinfection with roseoloviruses in general is not well understood, including in the context of AD. Further evaluation of reinfection could provide important information regarding the role of roseoloviruses in AD. An important consideration for our studies and future studies is that the mechanism of MRV spread within tissue could impact $A \beta$ accumulation. Human roseolovirus infection is thought to be largely cell-associated or through exosomes, which could make them less accessible to extracellular $A \beta$ aggregation [68]. Perhaps higher viral loads resulting in increased extracellular MRV-A $\beta$ interaction is necessary to increase $A \beta$ plaque formation, which may be why we did not observe $A \beta$ accumulation in 5XFAD mice that have an intact immune system.

While MRV infection did not result in increased $A \beta$, we determined that MRV interacts with $A \beta$, and that it infects the brain and acutely induces neuroinflammation. Whether MRV has cell-specific tropism is also unknown. It is possible that $A \beta$ entrapment of viral pathogens facilitated $A \beta$ seeding, but upregulation of diseaseassociated microglia rapidly assisted in the phagocytosis and removal of $A \beta$ plaques before further seeding and spreading of $A \beta$ could occur. However, as there were no differences between viral load in the cortex of WT and 5XFAD mice, if $\mathrm{A} \beta$ indeed sequestered MRV, it likely did not neutralize sufficient viral load to prevent further replication. Additional research could provide insight into CNS cell types that are especially vulnerable to 
infection which may result in $A \beta$-independent toxic effects. Furthermore, it has been suggested that genetic variation resulting in an altered immune response to pathogens could contribute to viral load and reactivation in $\operatorname{AD}[19,69]$. Our study utilized inbred mouse strains (5XFAD mice on a B6SJL background) that do not have immunodeficiency, but it is possible that MRV infection of mice with defects in genes involved in viral immune response could cause increased $A \beta$ load due to higher viral burden during acute infection or reactivation. For example, miR-155 knockout mice crossed to an APP/ PS1 mouse developed increased A $\beta$ load in the cortex compared to APP/PS1 controls [19]. miR-155 has been suggested to be important in controlling herpesvirus latency and is downregulated during lytic HHV-6 replication in NK cells [70, 71]. MRV infection of miR-155 knockout, or other mice with altered viral immune response mice could provide new insight into the relationship between immune control of roseolovirus lytic and latent infection and AD.

Our findings in this study do not support or refute the antimicrobial protection hypothesis of $A \beta$. However, our results suggest that HHV-6 is not a main contributor for increased AD risk in humans at a population level. MRV infections, like human roseolovirus infections, are well controlled in immunocompetent hosts and do not result in mortality. Neonatal infection of WT and 5XFAD mice resulted in similar levels of MRV DNA and RNA in the cortex $7 \mathrm{dpi}$, suggesting $A \beta$ has minimal, if any, antiviral properties towards neutralizing MRV after infection in 5XFAD mice. Although some markers of inflammation trended higher in the 5XFAD mice compared to WT littermates, these differences were not statistically significant. Despite this, a major finding in the current study was that MRV actively infects the brain and stimulates an inflammatory response, even after peripheral infection. Moreover, we found that $A \beta$ interacts with MRV in vitro and, subsequent to this interaction, inhibits in vivo infection. In addition to further studies of the relationship between MRV and AD-like phenotypes in mice, MRV could be studied in other diseases characterized by CNS inflammation. Human roseoloviruses have been associated with several other inflammatory and autoimmune CNS diseases, including viral encephalitis, multiple sclerosis, and Rasmussen encephalitis [72-74]. Given the limitations of current mouse models of roseolovirus infection, MRV could be highly useful for performing deliberate, controlled studies to uncover the mechanistic role of a roseolovirus in CNS disease.

\section{Conclusion}

Human roseoloviruses, HHV-6 and HHV-7 have recently been investigated for their role in $\mathrm{AD}$, although studies in humans have provided controversial results.
MRV is highly related to the human roseoloviruses, allowing for evaluation of the role of a natural murine roseolovirus in neuroinflammation and $A \beta$ accumulation. Although $A \beta$ interacted with MRV and disrupted infection, we found that MRV did not induce increased $A \beta$ load after peripheral or direct CNS infection. However, we demonstrated that MRV actively infects the brain and induces neuroinflammation, providing a suitable in vivo system for further studies of the impact of roseolovirus infection of the brain.

\section{Abbreviations}

5XFAD: 5 familial AD mutations; Aß: amyloid- $\beta$; AD: Alzheimer disease; APP: amyloid precursor protein; CNS: central nervous system; CDR: Clinical Dementia Rating; DNA: Deoxyribonucleic acid; DP: double positive; Dpi: days post infection; ELISA: Enzyme-linked immunosorbent assay; Gfap: Glial fibrillary acidic protein; $\mathrm{HCl}$ : Hydrochloric; HHV: human herpesvirus; Hpi: hours post infection; HRP: Horseradish peroxidase; HSV: herpes simplex virus; Iba1: Ionized calcium binding adaptor molecule 1; IL-6: Interleukin-6; IL-1 ß: Interleukin-1 beta; i.p.: intraperitoneal; Knight ADRC: Knight Alzheimer's Disease Research Center; miR: microRNA; Mpi: months post infection; MRV: murine roseolovirus; NSTEM: Negative staining transmission electron microscope; PSEN1: Presenilin 1; RNAseq: Ribonucleic acid sequencing; qPCR: Quantitative polymerase chain reaction; SEM: Standard error of the mean; SP: single positive; TBS: Tris-buffered saline; Trem2: Triggering Receptor Expressed On Myeloid Cells 2; Wpi: weeks post infection; WT: wild-type

\section{Supplementary Information}

The online version contains supplementary material available at https:/doi. org/10.1186/s13024-021-00514-8.

\begin{abstract}
Additional file 1: Supplementary Fig. 1. Peripheral, neonatal MRV infection in 5XFAD mice does not accelerate $A \beta$ plaque burden. A, Schematic of experimental paradigm ( $6 \mathrm{mpi}$ ). B, C, Percent of $\mathrm{CD}^{+}$and $\mathrm{CD}^{+} \mathrm{T}$ cells in plasma $10 \mathrm{dpi}(\mathbf{B})$ or $6 \mathrm{mpi}(\mathbf{C})$. D, E, HJ3.4B ${ }^{+}$ immunostaining for $A \beta$ plaque load in the cortex. F-I, Staining and quantification for Tau $5^{+}$total tau $(\mathbf{F}, \mathbf{G})$ and $\mathrm{AT}^{+}$phosphorylated tau in the cortex $(\mathbf{H}, \mathbf{I})$. J, Schematic of experimental paradigm ( 6 wpi). $\mathbf{K}, \mathbf{L}$, Percent area $\mathrm{HJ} 3.4 \mathrm{~B}^{+} \mathrm{A} \beta$ immunoreactivity $(A \beta-\mathrm{IR})$ in cortex. Dpi: days post infection. Mpi: months post infection. Wpi: weeks post infection. $\mathrm{p}$ tau: phosphorylated tau. Scale bar: $500 \mu \mathrm{m}$. Data expressed as mean \pm SEM, student's t-test (B, C, E, G, J, M). No statistical comparisons are significant unless indicated.
\end{abstract}

Additional file 2: Supplementary Fig. 2. Comparisons between MRV purified and unpurified stocks. A - C, Stocks were created from in vivo passage and collection of 7 day post neonatal infection thymi and were used directly (MRV Stock) or semi-purified (MRV Purified). BALB/c mice were mock- or MRV-infected with MRV Stock or MRV Purified via i.p. injection on P0 then were evaluated by flow cytometry for percent $\mathrm{CD}^{+}$cells per total $\mathrm{CD}^{+}$cells from the spleen at $7 \mathrm{dpi}(\mathbf{A})$ or weight at $7 \mathrm{dpi}(\mathbf{B}) . \mathbf{C}$, Copies of MRV DNA per $\mathrm{mL}$ of stock were evaluated by $\mathrm{qPCR}$.

Additional file 3: Supplementary Fig. 3. Effects of acute, intrahippocampal MRV infection on tau pathology. A, Schematic of experimental paradigm. B - G, Staining and quantification for Tau $5^{+}$total tau $(\mathbf{B}, \mathbf{C}, \mathbf{D})$ and $\mathrm{AT}^{+}{ }^{+}$phosphorylated tau in the cortex $(\mathbf{E}, \mathbf{F}, \mathbf{G})$. p-tau: phosphorylated tau. Scale bar: $500 \mu \mathrm{m}$. Data expressed as mean \pm SD, student's t-test. ${ }^{*} P<0.05$. ns $=$ not statistically significant. No statistical comparisons are significant unless indicated.

\section{Acknowledgements}

We thank the Hope Center Alafi Neuroimaging Laboratory for images scanned on a NanoZoomer digital pathology system. We acknowledge Michael Rau, Dr. Brock Summers and John Wulf II at Washington University Center for Cellular Imaging (WUCCI) center for preparing NS samples. NSTEM imaging was performed in part through the use of WUCCI supported by Washington University School of Medicine, The Children's Discovery 
Institute of Washington University and St. Louis Children's Hospital (CDICORE-2015-505 and CDI-CORE-2019-813) and the Foundation for BarnesJewish Hospital (3770 and 4642).

\section{Authors' contributions}

Conceptualization, T.M.B., M.X., C.C., M.A., S.J.P. D.M.H., and W.M.Y; Methodology, T.M.B., M.X., C.C., M.A., Y.C., C.W.; Investigation, T.M.B., M.X., Y.C., C.C., M.A., C.W., J.R.S., A. E, O.H., L.Y.; Writing - Original Draft, T.M.B., M.X., M.A., C.C., D.M.H. and W.M.Y; Writing - Review \& Editing, T.M.B., M.X., C.C., M.A., Y.C., C.W., D.M.H., and W.M.Y. Resources, T.M.B., M.X., C.C., M.A., D.M.H., and W.M.Y.; Supervision, T.M.B., M.X., C.C., M.A., Y.C., C.W., S.J.P., D.M.H., and W.M.Y.; Funding Acquisition, T.M.B., M.X., O.H., C.C., D.M.H. and W.M.Y. All authors read and approved the manuscript.

\section{Funding}

This work was supported by NIH grants T32Al106688-07 (T.M.B), T32AR007279-40 (T.M.B.), National Institute on Aging grant AG062027 (M.X.), $\mathrm{NIH}$ grants R01AG044546 (C.C.), P01AG003991 (C.C.), P30AG066444 (C.C.), RF1AG053303 (C.C.), RF1AG058501 (C.C.), U01AG058922 (C.C.), R01AG057777 (O.H.), Barnes-Jewish Hospital Foundation (W.M.Y.), R01AG047644 (D.M.H.), and R01NS090934 (D.M.H.). O. H is an Archer Foundation Research Scientist.

\section{Availability of data and materials}

Generated datasets used for analyses in this study are available from the corresponding author upon reasonable request.

\section{Declarations}

\section{Ethics approval and consent to participate}

All participants gave prospective postmortem written consent for their brains to be used for research.

\section{Consent for publication}

Not applicable.

\section{Competing interests}

D.M.H. is as an inventor on a patent licensed by Washington University to C2N Diagnostics on the therapeutic use of anti-tau antibodies. D.M.H. COfounded and is on the scientific advisory board of C2N Diagnostics. C2N Diagnostics has licensed certain anti-tau antibodies to AbbVie for therapeutic development. D.M.H. is on the scientific advisory board of Denali, Genentech, and Cajal Neurosciences and consults for Eli Lilly. The lab of D.M.H. receives research grants from the National Institutes of Health, Cure Alzheimer's Fund, Tau Consortium, the JPB Foundation, Good Ventures, C2N Diagnostics, NextCure, Novartis, and Denali. C.C. receives research support from Biogen, EISAI, Alector and Parabon. C.C. is a member of the advisory board of Vivid genetics, Halia Therapeutics and ADx Healthcare. All other authors declare that they have no competing interests.

\section{Author details}

'Division of Rheumatology, Department of Pediatrics, Washington University School of Medicine, St. Louis, MO 63110, USA. ²Department of Neurology, Hope Center for Neurological Disorders, Knight Alzheimer's Disease Research Center, Washington University School of Medicine, St. Louis, MO 63110, USA. ${ }^{3}$ Division of Biology and Biomedical Sciences (DBBS), Washington University School of Medicine, St. Louis, MO 63110, USA. ${ }^{4}$ Present address: Genentech, 1 DNA Way, South San Francisco, CA 94080, USA. ${ }^{5}$ Department of Pathology \& Immunology, Washington University School of Medicine, St. Louis, MO 63110, USA. ${ }^{6}$ Department Psychiatry, Washington University School of Medicine (WUSM), 660 S. Euclid Ave. B8134, St. Louis, MO 63110, USA. ${ }^{7}$ NeuroGenomics and Informatics, Washington University School of Medicine, St. Louis, MO, USA. ${ }^{8}$ Division of Rheumatology, Department of Medicine, Washington University School of Medicine, St. Louis, MO 63110, USA.

\section{Received: 8 July 2021 Accepted: 22 December 2021}

\section{Published online: 15 January 2022}

\section{References}

1. Long JM, Holtzman DM. Alzheimer disease: an update on pathobiology and treatment strategies. Cell. 2019;179(2):312-39. https://doi.org/10.1016/j.cell.2 019.09.001.
2. Soscia SJ, Kirby JE, Washicosky KJ, Tucker SM, Ingelsson M, Hyman B, et al. The Alzheimer's disease-associated amyloid beta-protein is an antimicrobial peptide. PLoS One. 2010;5(3):e9505. https://doi.org/10.1371/journal.pone. 0009505.

3. Bourgade K, Dupuis G, Frost EH, Fulop T. Anti-viral properties of amyloidbeta peptides. J Alzheimers Dis. 2016;54(3):859-78. https://doi.org/10.3233/ JAD-160517.

4. Kumar DK, Choi SH, Washicosky KJ, Eimer WA, Tucker S, Ghofrani J, et al. Amyloid-beta peptide protects against microbial infection in mouse and worm models of Alzheimer's disease. Sci Transl Med. 2016;8(340):340ra72.

5. Eimer WA, Vijaya Kumar DK, Navalpur Shanmugam NK, Rodriguez AS, Mitchell T, Washicosky KJ, et al. Alzheimer's disease-associated beta-amyloid is rapidly seeded by Herpesviridae to protect against brain infection. Neuron. 2018;99(1):56-63.e3. https://doi.org/10.1016/j.neuron.2018.06.030.

6. Haas JG, Lathe R. Microbes and Alzheimer's disease: new findings call for a paradigm change. Trends Neurosci. 2018;41(9):570-3. https://doi.org/10.101 6/j.tins.2018.07.001.

7. Leibovitch EC, Jacobson S. Viruses in chronic progressive neurologic disease. Mult Scler. 2018;24(1):48-52. https://doi.org/10.1177/1352458517737392.

8. Kvestak D, Juranic Lisnic V, Lisnic B, Tomac J, Golemac M, Brizic I, et al. NK ILC1 cells mediate neuroinflammation and brain pathology following congenital CMV infection. J Exp Med. 2021;218(5):e20201503.

9. Wozniak MA, Shipley SJ, Combrinck M, Wilcock GK, Itzhaki RF. Productive herpes simplex virus in brain of elderly normal subjects and Alzheimer's disease patients. J Med Virol. 2005;75(2):300-6. https://doi.org/10.1002/jmv.2 0271.

10. Wozniak MA, Mee AP, Itzhaki RF. Herpes simplex virus type 1 DNA is located within Alzheimer's disease amyloid plaques. J Pathol. 2009;217(1):131-8. https://doi.org/10.1002/path.2449.

11. Letenneur L, Peres K, Fleury H, Garrigue I, Barberger-Gateau P, Helmer C, et al. Seropositivity to herpes simplex virus antibodies and risk of Alzheimer's disease: a population-based cohort study. PLoS One. 2008;3(11): e3637. https://doi.org/10.1371/journal.pone.0003637.

12. Lovheim H, Olsson J, Weidung B, Johansson A, Eriksson S, Hallmans G, et al. Interaction between cytomegalovirus and herpes simplex virus type 1 associated with the risk of Alzheimer's disease development. J Alzheimers Dis. 2018;61(3):939-45. https://doi.org/10.3233/JAD-161305.

13. Rizzo R. Controversial role of herpesviruses in Alzheimer's disease. PLoS Pathog. 2020;16(6):e1008575. https://doi.org/10.1371/journal.ppat.1008575.

14. Allnutt MA, Johnson K, Bennett DA, Connor SM, Troncoso JC, Pletnikova O, et al. Human herpesvirus 6 detection in Alzheimer's disease cases and controls across multiple cohorts. Neuron. 2020;105(6):1027-35.e2. https://doi. org/10.1016/j.neuron.2019.12.031.

15. Leibovitch EC, Brunetto GS, Caruso B, Fenton K, Ohayon J, Reich DS, et al. Coinfection of human herpesviruses $6 \mathrm{~A}(\mathrm{HHV}-6 \mathrm{~A})$ and $\mathrm{HHV}-6 \mathrm{~B}$ as demonstrated by novel digital droplet PCR assay. PLoS One. 2014;9(3): e92328. https://doi.org/10.1371/journal.pone.0092328.

16. Komaroff AL, Pellett PE, Jacobson S. Human Herpesviruses $6 \mathrm{~A}$ and $6 \mathrm{~B}$ in Brain Diseases: Association versus Causation. Clin Microbiol Rev. 2020;34(1): e00143-20.

17. Lin WR, Wozniak MA, Cooper RJ, Wilcock GK, Itzhaki RF. Herpesviruses in brain and Alzheimer's disease. J Pathol. 2002;197(3):395-402. https://doi. org/10.1002/path.1127.

18. Rizzo R, Bortolotti D, Gentili V, Rotola A, Bolzani S, Caselli E, et al. KIR2DS2/ KIR2DL2/HLA-C1 haplotype is associated with Alzheimer's disease: implication for the role of herpesvirus infections. J Alzheimers Dis. 2019; 67(4):1379-89. https://doi.org/10.3233/JAD-180777.

19. Readhead B, Haure-Mirande JV, Funk CC, Richards MA, Shannon P, Haroutunian $V$, et al. Multiscale analysis of independent Alzheimer's cohorts finds disruption of molecular, genetic, and clinical networks by human herpesvirus. Neuron. 2018;99(1):64-82.e7. https://doi.org/10.1016/..neuron.2018.05.023.

20. Jeong HH, Liu Z. Are HHV-6A and HHV-7 really more abundant in Alzheimer's disease. Neuron. 2019;104(6):1034-5. https://doi.org/10.1016/j. neuron.2019.11.009.

21. Agut $H$, Bonnafous $P$, Gautheret-Dejean A. Update on infections with human herpesviruses 6A, 6B, and 7. Med Mal Infect. 2017;47(2):83-91. https://doi.org/10.1016/j.medmal.2016.09.004.

22. Cuende JI, Ruiz J, Civeira MP, Prieto J. High prevalence of HHV-6 DNA in peripheral blood mononuclear cells of healthy individuals detected by nested-PCR. J Med Virol. 1994;43(2):115-8. https://doi.org/10.1002/jmv.1 890430203. 
23. Wang B, Saito Y, Nishimura M, Ren Z, Tjan LH, Refaat A, et al. An Animal Model That Mimics Human Herpesvirus 6B Pathogenesis. J Virol. 2020;94(6): e01851-19.

24. Tanner A, Carlson SA, Nukui M, Murphy EA, Berges BK. Human herpesvirus $6 \mathrm{~A}$ infection and immunopathogenesis in humanized Rag2(-)/(-) gammac(-)/(-) mice. J Virol. 2013;87(22):12020-8. https://doi.org/10.1128/ JVI.01556-13.

25. Reynaud JM, Jegou JF, Welsch JC, Horvat B. Human herpesvirus 6A infection in CD46 transgenic mice: viral persistence in the brain and increased production of proinflammatory chemokines via toll-like receptor 9. J Virol. 2014;88(10):5421-36. https://doi.org/10.1128/JVI.03763-13.

26. Patel SJ, Zhao G, Penna VR, Park E, Lauron EJ, Harvey IB, et al. A Murine Herpesvirus Closely Related to Ubiquitous Human Herpesviruses Causes TCell Depletion. J Virol. 2017;91(9):e02463-16.

27. Becker SD, Bennett M, Stewart JP, Hurst JL. Serological survey of virus infection among wild house mice (Mus domesticus) in the UK. Lab Anim. 2007:41(2):229-38. https://doi.org/10.1258/002367707780378203.

28. Cross SS, Parker JC, Rowe WP, Robbins ML. Biology of mouse thymic virus, a herpesvirus of mice, and the antigenic relationship to mouse cytomegalovirus. Infect Immun. 1979;26(3):1186-95. https://doi.org/10.1128/ iai.26.3.1186-1195.1979.

29. Patel SJ, Yokoyama WM. CD8(+) T cells prevent lethality from neonatal murine Roseolovirus infection. J Immunol. 2017;199(9):3212-21. https://doi. org/10.4049/jimmunol.1700982.

30. Oakley H, Cole SL, Logan S, Maus E, Shao P, Craft J, et al. Intraneuronal betaamyloid aggregates, neurodegeneration, and neuron loss in transgenic mice with five familial Alzheimer's disease mutations: potential factors in amyloid plaque formation. J Neurosci. 2006;26(40):10129-40. https://doi. org/10.1523/JNEUROSCI.1202-06.2006

31. Stinski MF. Human cytomegalovirus: glycoproteins associated with virions and dense bodies. J Virol. 1976;19(2):594-609. https://doi.org/10.1128/jvi.1 9.2.594-609.1976

32. Amen MA, Griffiths A. Identification and expression analysis of herpes $B$ virus-encoded small RNAs. J Virol. 2011;85(14):7296-311. https://doi.org/1 0.1128/JVI.00505-11.

33. Stine $W B$, Jungbauer $L, Y u C$, LaDu MJ. Preparing synthetic Abeta in different aggregation states. Methods Mol Biol. 2011;670:13-32. https://doi. org/10.1007/978-1-60761-744-0_2.

34. Xiong $M$, Jiang $H$, Serrano JR, Gonzales ER, Wang C, Gratuze $M$, et al. APOE immunotherapy reduces cerebral amyloid angiopathy and amyloid plaques while improving cerebrovascular function. Sci Transl Med. 2021;13(581): eabd7522.

35. Liao F, Li A, Xiong M, Bien-Ly N, Jiang H, Zhang Y, et al. Targeting of nonlipidated, aggregated apoE with antibodies inhibits amyloid accumulation. J Clin Invest. 2018;128(5):2144-55. https://doi.org/10.1172/ JC196429.

36. Dube U, Del-Aguila JL, Li Z, Budde JP, Jiang S, Hsu S, et al. An atlas of cortical circular RNA expression in Alzheimer disease brains demonstrates clinical and pathological associations. Nat Neurosci. 2019;22(11):1903-12. https://doi.org/10.1038/s41593-019-0501-5.

37. Li Z, Del-Aguila JL, Dube U, Budde J, Martinez R, Black K, et al. Genetic variants associated with Alzheimer's disease confer different cerebral cortex cell-type population structure. Genome Med. 2018;10(1):43. https://doi.org/1 0.1186/s13073-018-0551-4.

38. Del-Aguila JL, Benitez BA, Li Z, Dube U, Mihindukulasuriya KA, Budde JP, et al. TREM2 brain transcript-specific studies in AD and TREM2 mutation carriers. Mol Neurodegener. 2019;14(1):18. https://doi.org/10.1186/s13024-01 9-0319-3.

39. Li Z, Farias FHG, Dube U, Del-Aguila JL, Mihindukulasuriya KA, Fernandez MV, et al. The TMEM106B FTLD-protective variant, rs1990621, is also associated with increased neuronal proportion. Acta Neuropathol. 2020; 139(1):45-61. https://doi.org/10.1007/s00401-019-02066-0.

40. Harrow J, Frankish A, Gonzalez JM, Tapanari E, Diekhans M, Kokocinski F, et al. GENCODE: the reference human genome annotation for the ENCODE project. Genome Res. 2012;22(9):1760-74. https://doi.org/10.1101/gr.1353 50.111.

41. Dobin A, Davis CA, Schlesinger F, Drenkow J, Zaleski C, Jha S, et al. STAR: ultrafast universal RNA-seq aligner. Bioinformatics. 2013;29(1):15-21. https:// doi.org/10.1093/bioinformatics/bts635.

42. Wickham H. ggplot2: Elegant Graphics for Data Analysis: Springer-Verlag; 2016. https://ggplot2-book.org/.
43. Haynes W. Wilcoxon Rank Sum Test. In: WO DW, Cho KH, Yokota H, editors. Encyclopedia of Systems Biology. New York: Springer; 2013.

44. Walker MA, Pedamallu CS, Ojesina Al, Bullman S, Sharpe T, Whelan CW, et al. GATK PathSeq: a customizable computational tool for the discovery and identification of microbial sequences in libraries from eukaryotic hosts. Bioinformatics. 2018;34(24):4287-9. https:/doi.org/10.1093/bioinformatics/bty501.

45. Gruffat H, Marchione R, Manet E. Herpesvirus late gene expression: a viralspecific pre-initiation complex is key. Front Microbiol. 2016;7:869. https://doi. org/10.3389/fmicb.2016.00869.

46. Keren-Shaul H, Spinrad A, Weiner A, Matcovitch-Natan O, Dvir-Szternfeld R, Ulland TK, et al. A unique microglia type associated with restricting development of Alzheimer's disease. Cell. 2017;169(7):1276-90.e17. https:// doi.org/10.1016/j.cell.2017.05.018

47. Habib N, McCabe C, Medina S, Varshavsky M, Kitsberg D, Dvir-Szternfeld R, et al. Disease-associated astrocytes in Alzheimer's disease and aging. Nat Neurosci. 2020;23(6):701-6. https://doi.org/10.1038/s41593-020-0624-8.

48. White MR, Kandel R, Tripathi S, Condon D, Qi L, Taubenberger J, et al. Alzheimer's associated beta-amyloid protein inhibits influenza a virus and modulates viral interactions with phagocytes. PLoS One. 2014;9(7):e101364. https://doi.org/10.1371/journal.pone.0101364.

49. Arnusch CJ, Branderhorst $H$, de Kruijff B, Liskamp RM, Breukink E, Pieters RJ. Enhanced membrane pore formation by multimeric/oligomeric antimicrobial peptides. Biochemistry. 2007;46(46):13437-42. https://doi.org/1 0.1021/bi7015553.

50. Moir RD, Lathe R, Tanzi RE. The antimicrobial protection hypothesis of Alzheimer's disease. Alzheimers Dement. 2018;14(12):1602-14. https://doi. org/10.1016/j.jalz.2018.06.3040.

51. Hoover DM, Rajashankar KR, Blumenthal R, Puri A, Oppenheim JJ, Chertov O, et al. The structure of human beta-defensin-2 shows evidence of higher order oligomerization. J Biol Chem. 2000;275(42):32911-8. https://doi.org/1 0.1074/jbc.M006098200.

52. Sy M, Kitazawa M, Medeiros R, Whitman L, Cheng D, Lane TE, et al. Inflammation induced by infection potentiates tau pathological features in transgenic mice. Am J Pathol. 2011;178(6):2811-22. https://doi.org/10.1016/j.ajpath.2011.02.012

53. Romeo MA, Gilardini Montani MS, Gaeta A, D'Orazi G, Faggioni A, Cirone M. HHV-6A infection dysregulates autophagy/UPR interplay increasing beta amyloid production and tau phosphorylation in astrocytoma cells as well as in primary neurons, possible molecular mechanisms linking viral infection to Alzheimer's disease. Biochim Biophys Acta Mol basis Dis. 1866;2020(3): 165647. https://doi.org/10.1016/j.bbadis.2019.165647.

54. Wozniak MA, Frost AL, Itzhaki RF. Alzheimer's disease-specific tau phosphorylation is induced by herpes simplex virus type 1. J Alzheimers Dis. 2009;16(2):341-50. https://doi.org/10.3233/JAD-2009-0963.

55. Eimer WA, Vijaya Kumar DK, Navalpur Shanmugam NK, Rodriguez AS, Mitchell T, Washicosky KJ, et al. Alzheimer's disease-associated beta-amyloid is rapidly seeded by Herpesviridae to protect against brain infection. Neuron. 2018;100(6):1527-32. https://doi.org/10.1016/j.neuron.2018.11.043.

56. Agostini S, Mancuso R, Baglio F, Cabinio M, Hernis A, Guerini FR, et al. Lack of evidence for a role of HHV-6 in the pathogenesis of Alzheimer's disease. J Alzheimers Dis. 2016;49(1):229-35. https://doi.org/10.3233/JAD-150464.

57. Hemling N, Roytta M, Rinne J, Pollanen P, Broberg E, Tapio V, et al. Herpesviruses in brains in Alzheimer's and Parkinson's diseases. Ann Neurol. 2003:54(2):267-71. https://doi.org/10.1002/ana.10662.

58. St-Pierre Y, Potworowski EF, Lussier G. Transmission of mouse thymic virus. J Gen Virol. 1987;68(Pt 4):1173-6. https://doi.org/10.1099/0022-1317-68-4-1173.

59. De Chiara G, Piacentini R, Fabiani M, Mastrodonato A, Marcocci ME, Limongi $D$, et al. Recurrent herpes simplex virus-1 infection induces hallmarks of neurodegeneration and cognitive deficits in mice. PLoS Pathog. 2019;15(3): e1007617. https://doi.org/10.1371/journal.ppat.1007617.

60. Bocharova OM, Molesworth K, Pandit NP, Baskakov IV. Alzheimer's DiseaseAssociated $\beta$-Amyloid Does Not Protect Against Herpesviridae Brain Infection: Cell Press Sneak Peek; 2021. https://doi.org/10.1016/j.jbc.2021.100845.

61. Lopatko Lindman K, Hemmingsson ES, Weidung B, Brannstrom J, Josefsson $\mathrm{M}, \mathrm{Olsson} J$, et al. Herpesvirus infections, antiviral treatment, and the risk of dementia-a registry-based cohort study in Sweden. Alzheimers Dement ( $N$ Y). 2021;7(1):e12119.

62. Tzeng NS, Chung CH, Lin FH, Chiang CP, Yeh CB, Huang SY, et al. Antiherpetic medications and reduced risk of dementia in patients with herpes simplex virus infections-a nationwide, population-based cohort study in Taiwan. Neurotherapeutics. 2018;15(2):417-29. https://doi.org/10.1007/ s13311-018-0611-x. 
63. Bae S, Yun SC, Kim MC, Yoon W, Lim JS, Lee SO, et al. Association of herpes zoster with dementia and effect of antiviral therapy on dementia: a population-based cohort study. Eur Arch Psychiatry Clin Neurosci. 2020; 271(5):987-97. https://doi.org/10.1007/s00406-020-01157-4.

64. Schnier C, Janbek J, Williams L, Wilkinson T, Laursen TM, Waldemar G, et al. Antiherpetic medication and incident dementia: observational cohort studies in four countries. Eur J Neurol. 2021;28(6):1840-8. https://doi.org/1 0.1111/ene.14795.

65. Kikuta H, Lu H, Matsumoto S. Susceptibility of human herpesvirus 6 to acyclovir. Lancet. 1989;2(8667):861. https://doi.org/10.1016/50140-6736(89)93 019-5.

66. Agut $\mathrm{H}$, Huraux JM, Collandre $\mathrm{H}$, Montagnier L. Susceptibility of human herpesvirus 6 to acyclovir and ganciclovir. Lancet. 1989;2(8663):626. https:// doi.org/10.1016/S0140-6736(89)90754-X.

67. Burns WH, Sandford GR. Susceptibility of human herpesvirus 6 to antivirals in vitro. J Infect Dis. 1990;162(3):634-7. https://doi.org/10.1093/infdis/162.3. 634.

68. Mori Y, Koike M, Moriishi E, Kawabata A, Tang H, Oyaizu H, et al. Human herpesvirus-6 induces MVB formation, and virus egress occurs by an exosomal release pathway. Traffic. 2008;9(10):1728-42. https://doi.org/1 0.1111/j.1600-0854.2008.00796.x.

69. Marsh SE, Abud EM, Lakatos A, Karimzadeh A, Yeung ST, Davtyan H, et al. The adaptive immune system restrains Alzheimer's disease pathogenesis by modulating microglial function. Proc Natl Acad Sci U S A. 2016;113(9): E1316-25. https://doi.org/10.1073/pnas.1525466113.

70. Bhela S, Mulik S, Reddy PB, Richardson RL, Gimenez F, Rajasagi NK, et al. Critical role of microRNA-155 in herpes simplex encephalitis. J Immunol. 2014;192(6):2734-43. https://doi.org/10.4049/jimmunol.1302326.

71. Rizzo R, Soffritti I, D'Accolti M, Bortolotti D, Di Luca D, Caselli E. HHV-6A/6B infection of NK cells modulates the expression of miRNAs and transcription factors potentially associated to impaired NK activity. Front Microbiol. 2017; 8:2143. https://doi.org/10.3389/fmicb.2017.02143.

72. Caselli E, Soffritti I, D'Accolti M, Bortolotti D, Rizzo R, Sighinolfi G, et al. HHV6A Infection and Systemic Sclerosis: Clues of a Possible Association. Microorganisms. 2019;8(1):39.

73. Sun XW, Liu CM, Teng ZQ. Commentary: multiscale analysis of independent Alzheimer's cohorts finds disruption of molecular, genetic, and clinical networks by human herpesvirus. Front Mol Neurosci. 2018;11:340. https:// doi.org/10.3389/fnmol.2018.00340.

74. Gewurz BE, Marty FM, Baden LR, Katz JT. Human herpesvirus 6 encephalitis. Curr Infect Dis Rep. 2008;10(4):292-9. https://doi.org/10.1007/s11908-0080048-1.

\section{Publisher's Note}

Springer Nature remains neutral with regard to jurisdictional claims in published maps and institutional affiliations.

Ready to submit your research? Choose BMC and benefit from:

- fast, convenient online submission

- thorough peer review by experienced researchers in your field

- rapid publication on acceptance

- support for research data, including large and complex data types

- gold Open Access which fosters wider collaboration and increased citations

- maximum visibility for your research: over $100 \mathrm{M}$ website views per year

At $\mathrm{BMC}$, research is always in progress.

Learn more biomedcentral.com/submissions 